\title{
Om Grundtvig-Selskabet 1947-1997 - et tilbageblik
}

\author{
Af William Michelsen
}

Når man har oplevet tiden før Grundtvig-Selskabets stiftelse, dets fødsel og de første halvtreds år af dets liv, kan man ikke undgå at spørge sig selv: hvorfor blev det ikke stiftet før? - Hvorfor blev det stiftet netop for 50 år siden? Og hvorledes har det udviklet sig til det, det er nu? - Fremtiden kender vi ikke. Den beror ligesom fortiden på medlemmernes interesse for selskabets hensigt: at være forum for Grundtvigforskningen, at $\varnothing \mathrm{ge}$ og fastholde interessen for Grundtvigs indsats i dansk kultur såvel i poesi som i prosa, såvel som taler og prædikant som i skrift og på tryk - og at forøge kendskabet til dette vort mest omfattende forfatterskab og dets virkning såvel her i Danmark som uden for Danmark. Mindre var de forestillinger, vi der besluttede at stifte Grundtvig-Selskabet havde, ikke. Og det er mig naturligt nok en stor glæde at se, at denne hensigt stadig omfattes med så stor interesse, som man kan se af det brogede indhold, hvoraf vor årbog Grundtvig-Studier nu består; det gælder både hvad emnerne og hvad deres forfatteres sprog, interesser og hensigter angår. Det var netop noget sådant, vi forestillede os som hensigten med at stifte dette lærde selskab.

Men det var ikke med denne hensigt, biskoppen og stiftsprovsten i Ribe havde sammenkaldt det møde mellem seks Grundtvigforskere, ved hvilket beslutningen om at stifte Grundvig-Selskabet blev taget. Det blev først under selve mødet klart for os, at der var brug for en fortsat kontakt ikke blot mellem os, men mellem alle, der på en eller anden måde studerede og udforskede dette for en enkelt forsker uoverkommelige forfatterskab og dets virkninger, dets forudsætninger og dets forhold til samtiden. Men det stod os også klart, at vi ikke kunne danne en eksklusiv kreds af lærde. Vi ønskede tværtimod en stor skare af læsere og tilhørere, som kunne udbrede kendskabet til denne særegne digter, præst og videnskabsmand, der havde fængslet os selv.

Således gik det til, at Grundtvig-Selskabet kom til at bestå af to kredse medlemmer: Grundtvigforskerne og de $\emptyset$ vrige medlemmer. Vi forestillede os en kreds af foreløbig ca. 25 forskere og omkring 20 gange så mange andre medlemmer som det nødvendige publikum for de arbejder, vi allerede var i gang med og ønskede offentliggjort - 
foruden et ukendt antal interesserede læsere uden for selve medlemsskaren. Således fik Grundtvig-Selskabet den såkaldte »styrelse« på 25 forskere med et forretningsudvalg, bestånde af formand, næstformand, redaktør, sekretær og kasserer, og et åbent medlemskab af Grundtviginteresserede, som virkelig nåede op på et antal af henimod 500 medlemmer, undertiden lidt over, efterhånden lidt mindre, fordi de ældre medlemmer efterhånden faldt fra.

Hvorfor var et sådant selskab ikke stiftet før? - Mit svar er: simpelthen fordi Grundtvig var en så særegen og omstridt forfatter. Den situation befandt Grundtvig sig nemlig i fra sit kristne gennembrud $\mathrm{i}$ 1810 til sin død i 1872. Man var enten grundtvigianer eller ikkegrundtvigianer. Sjællands biskop J.P. Mynster, anså Grundtvigs indflydelse for den farligste $i$ den danske kirke, som det ses af hans »Meddelelser om mit Levnet «, som blev udgivet straks efter hans død i 1854. Grundtvigs salmer kom først ind i den autoriserede salmebog samtidig med Mynsters død. At de var af Grundtvig, kunne man kun se ved et opslag i forfatterlisten bag i bogen. Situationen kan belyses ved en anekdote, overleveret af en grundtvigiansk slægtning af min afdøde hustru. Komponisten H.C. Lumbye var i 1872 på vej over mod Tivoli, men standsedes på Vester Voldgade af et meget langt ligtog. »Hvem er det, der bliver begravet? « spurgte han. - En af følget svarede: »Grundtvig.« - »Det må have været en meget afholdt mand, "svarede Lumbye. Det var så at sige to forskellige verdener, der her stødte på hinanden, ubekendte for hinanden.

Situationen var ikke meget anderledes i 1931, da jeg begyndte at studere dansk og færdedes i Studiestræde i København. I den ene ende af strædet var Universitetsannexet med auditorier, laboratorier og frokoststue, i den anden ende "Grundtvigs Hus « med mødesal, Grundtvig-Bibliotek og »Studenterkredsen«s lokaler. - Ville man være sikker på at blive mæt på frokoststuen, valgte man et "grundtvigianerbrød«. At en juridisk professor ved universitetets årsfest midt i 1930erne valgte at holde forelæsning om Grundtvig som politiker, var en stor overraskelse.

Denne situation ændredes fuldstændig under den tyske besættelse 1940-45 ved professor $\mathrm{Hal} \mathrm{Kochs} \mathrm{Grundtvig-forelæsninger,} \mathrm{der} \mathrm{straks}$ blev udgivet som bog både på dansk og svensk. En vigtig begivenhed forud for Grundtvig-Selskabets stiftelse var også, at den grundtvigske forening Kirkeligt Samfund af 1898 flyttede sit domicil fra »Grundtvigs Hus« til den grundtvigske bevægelses egentlige arnested, den 
nedlagte alderdomsstiftelse Vartov (i Farvergade ved Rådhuspladsen), ved hvis kirke Grundtvig var præst fra 1839 til sin død. Det var Grundtvig-Selskabets første formand, biskop C.I. Scharling, der $\emptyset n-$ skede, at Grundtvig-Selskabet skulle have kontor i Vartov sammen med Kirkeligt Samfund, hvor kontorchef Leif Garsdal (som havde foreslået og gennemført flytningen til Vartov) også kom til at lede selskabets kontor. Vi har aldrig fortrudt dette samarbejde med Kirkeligt Samfund, som heller aldrig har været generet af, at Grundtvig-Selskabet aldrig er blevet et grundvigiansk foretagende, men har fastholdt, at selskabets hovedformål er et rent videnskabeligt studium af Grundtvigs forfatterskab uden stillingtagen til hans kirkelige standpunkt og kristne tro. - Jeg anser i $\varnothing$ vrigt denne adskillelse af videnskab og tro for at være i overensstemmelse med den modne Grundtvigs holdning.

Kun én frygt havde vi ved stiftelsen af dette selskab: at den bevægelse, Grundtvig havde fremkaldt, skulle træde hindrende i vejen for dette foretagende. Var det ikke »Skolen for Døden«, der her ville erobre Grundtvig og dermed »Skolen for Livet«, der havde etableret sig som modpol eller alternativ til universitetsdannelsen? - Vi var ikke et øjeblik i tvivl om, at en sådan protest mod Grundtvig-Selskabet ville være uberettiget. Grundtvig havde jo selv udkastet en plan for en videnskabelig højskole ved siden af den folkelige og talt om en »venlig vekselvirkning « mellem dem.

Ved at føje datoen for selskabets stiftelse, som er Grundtvigs fødselsdag, til dets navn ville vi sikre os, at ingen skulle kunne hindre oprettelsen af selskabet.

De seks Grundtvigforskere, der mødtes i Ribe, var tre teologer og tre humanister, så der var fra begyndelsen ligevægt mellem den kirkelige og den verdslige side af Grundtvigs forfatterskab. Det nærmeste, nogen af os hidtil havde været den grundtvigske bevægelse, var, at to af os havde deltaget i et grundtvigsk arbejdskonvent, som biskop Hans Øllgaard havde indbudt os til på Kerteminde Højskole. Henning Høirup og jeg kom så at sige direkte fra et sådant arbejdskonvent umiddelbart forud for forskermødet i Ribe. Skønt jeg ikke er teolog, var også jeg blevet indbudt til at tale om Grundtvigs historiesyn, og dér fandt mit første møde med Kaj Thaning sted.

Forskermødet i Ribe foregik i bispegården, og deltagerne var biskop C.I. Scharling, stiftsprovst Villiam Grønbaek, sognepræst Henning Hoirup, Ejby på Fyn, og cand. mag.erne Steen Johansen, Helge 
Toldberg og William Michelsen (ingen af os tre havde dengang nogen fast stilling). Hensigten med at kalde os sammen var simpelthen, at vi skulle oplyse hinanden om emnerne for vore forskninger, for at vi ikke skulle komme til at overflødiggøre hinandens arbejder. Jeg tillod mig forud for de egentlige redegørelser at sige, at jeg gik ud fra, at vi var enige om ikke at misbruge den viden, vi ved dette møde fik om hinandens forskninger og resultater. Det var nemlig bl.a. frygt for et sådant misbrug, der hidtil havde hindret sådanne forskermøder.

Ifølge den rapport om mødet, som Høirup citerer i sin samlede beretning om selskabets første ti år (i Grundtvig-Studier 1958) og som var forfattet af vores sekretær Helge Toldberg, skal jeg have været første taler og titelen på mit foredrag være den samme som titelen på min disputats, der først blev trykt i 1954. Men dét var i hvert fald ikke min oprindelige plan, og det var ikke mig, der indledte redeg $\varnothing$ relserne for de arbejder, vi var i gang med.

Den første taler var biskop Scharling, der ved denne lejlighed kunne fremlægge trykmanuskript og 1. korrektur på sin bog "Grundtvig og Romantiken, belyst ved Grundtvigs Forhold til Schelling «. Denne oplysning var på én gang et chok og en lettelse for mig. Jeg havde nemlig på daværende tidspunkt netop forestillet mig, at mit arbejde skulle dreje sig om Grundtvigs forhold til den romantiske bevægelse, og mit hovedproblem var netop at gøre rede for Grundtvigs forhold til Schelling. Jeg måtte derfor samme dag, inden jeg skulle gøre rede for mit arbejde, beslutte mig til at vælge et andet emne og en anden problemstilling. Jeg valgte da netop det problem, som ligger i titelen på min disputats, »Tilblivelsen af Grundtvigs historiesyn«, og jeg kunne derfor simpelthen gentage det foredrag, jeg få dage forinden havde holdt på det grundvigske arbejdskonvent. Mit emne blev derved på en meget gavnlig måde præciseret. Forholdet til romantikken, herunder også til Schelling, indgik stadig deri, men ikke som hovedsagen. Jeg behøvede slet ikke at bruge ordet »romantik «, men kunne i stedet tale om tysk idealistisk filosofi. Deraf lettelsen.

Villiam Grønbæks studier havde oprindelig drejet sig om den psykologiske baggrund for J.P. Mynsters liv og tænkning. Men han havde under sine studier af Mynster gjort den overraskende opdagelse, at Grundtvig var meget mere spændende, og hans studier kom derfor $\mathrm{i}$ stedet til at dreje sig om »Psykologiske tanker og teorier hos Grundtvig«, som titelen på hans bog senere kom til at lyde. Herom handlede hans redegørelse i Ribe derfor også. 
Henning Høirup havde under sit studium af Grundtvigs tænkning gjort den nyopdagelse, at Grundtvigs lærer i filosofi på universitetet, Riisbrigh, var modtander af Kants filosofi og stadig tænkte og underviste i overensstemmelse med Leibniz og Wolff, hvilket særlig viste sig deri, at han brugte modsigelsens grundsætning »ontologisk «, dvs. at han brugte den til at bevise religionens sandhed, mens Kant hævdede, at den blot er en formel logisk tankeregel. Dette forklarer, at Grundtvig mente at kunne forsvare kristendommens sandhed rent logisk, og at han f.eks. gjorde dette i 1825 i »Kirkens Gienmæle«!

Høirups manuskript var næsten færdigt til indlevering som disputats ved Københavns Universitet, men behøvede endnu en sidste afpudsning, og det var i høj grad vejledende for mig at kunne følge Høirups fremstilling af Grundtvigs tænkning i manuskript.

Den femte deltager i forskermødet, Steen Johansen, var på en måde den vigtigste, fordi hans arbejde bestod i at udarbejde en fuldstændig og udførlig bibliografi over hele Grundtvigs forfatterskab. Den kom til at bestå af fire store bind, hvoraf det første udkom allerede næste år, 1948. Ved hans redegørelse for sit minutiøse arbejde og dets vanskeligheder fik vi på én gang et indtryk af det kolossale omfang af Grundtvigs forfatterskab og fornemmelsen af at have en sikker grund for os alle at arbejde på. Vi fik også antydninger af et andet grundlæggende arbejde, som endnu ikke var kommet i gang, nemlig udarbejdelsen af en udførlig registrant over alle Grundtvigs efterladte manuskripter. Det begyndte at gå op for os, at biskop Scharling havde ret, da han brugte ordet »gigantisk« om dette forfatterskab.

Den sjette - og som det skulle vise sig den allerivrigste - af de seks Grundtvigforskere var min gode ven Helge Toldberg, som havde besluttet at skrive en disputats om symbolsproget i Grundtvigs verdslige digtning, at læse alle Grundtvigs »Poetiske Skrifter« som ét stort digt og gøre rede for dets billedsprog. Toldberg var student fra samme år som jeg selv, og vi havde så god kontakt med hinanden, at det aldrig kom til nogen alvorlige uoverensstemmelser mellem os, skønt jeg på visse punkter ikke var enig med ham og også havde kritiseret et af hans synspunkter - hvorvidt Grundtvig var profet i gammeltestamentlig forstand - i tidsskriftet »Orbis Litterarum«. Vi var også af professor Hal Koch blevet opfordret til at udarbejde et forslag til en fuldstændig Grundvigudgave. Ved forsøget herpå gik det op for os begge, at en sådan udgave ville blive så kæmpemæssig, 
at den ville kræve mere end ét menneskes hele liv. Og det veg vi tilbage for.

Hovedarbejdet i de første måneder efter Ribemødet bestod i at hverve medlemmer til selskabet og især at få de faktiske Grundtvigforskere til at blive medlemmer af »Styrelsen«. På 3. side af 1 . årgang af Grundtvig-Studier (1948) står følgende liste over Grundtvigforskere, der da var medlemmer af styrelsen udover de seks fra Ribemødet. (Vi havde valgt C.I. Scharling til formand, Henning Høirup til redaktør og Helge Toldberg til sekretær).

Seminarieforstander Georg Christensen, næstformand.

stud.theol. Morten Øllgaard, kasserer.

Universitetsadjunkt Gustav Albeck, dr. phil., Århus.

Pastor Th. Balslev, Vartov kirke.

Højskolelærer Dr. Holger Kjar, Askov.

Professor Dr. theol. Hal Koch, København.

Professor Ph.D. Kemp Malone, The Johns Hopkins University, Baltimore.

Professor Dr. theol. Regin Prenter. Århus.

Mag.art. Magnus Stevns, København.

Sognepræst Kaj Thaning, Asperup, Fyn.

Biskop H. Øllgaard, Odense, og

Overbibliotekar Vilhelm Grundtvig, Statsbiblioteket, Århus.

Ialt 20 styrelsesmedlemmer, når de 6 fra Ribe-mødet medregnes, heraf 4 professorer, 1 højskolelærer med doktortitel, 2 biskopper, 2 sognepræster, 1 stud. theol., 1 amerikansk professor, der var Beowulfforsker, og sidst, men ikke mindst en sønnesøn af N.F.S. Grundtvig - tilstrækkelig mange prominente personer og folk af grundtvigsk observans til, at balancen mellem universitetet og grundtvigianismen var til stede. Dette forhindrede imidlertid ikke en stærkt tilbageholdende stillingtagen fra den grundtvigske folkeh $\varnothing j-$ skoles side.

Grundtvig-Selskabet og redaktionen af Grundtvig-Studier har altid $\emptyset$ nsket at lade forskellige synspunkter komme til orde og således skabe en frugtbar nutidig debat om den virkelige Grundtvig. Hans tanker var dengang næsten kun fremstillet af traditionelt grundtvigsk orienterede, uden at anderledestænkende fik lejlighed til at ytre sig herom. Nu drejede det sig om at lade Grundtvig selv komme til orde, 
f.eks. gennem offentliggørelse af, hvad han har skrevet, men aldrig selv ladet trykke. Dertil behøvedes en i videnskabelig henseende korrekt fremstilling af hans tanker, således som de har udviklet sig hos ham gennem hele hans liv. Det er dette mål, der endnu ikke kan siges at være virkeliggjort, men som vores arbejde stadig går ud på at realisere.

Grundtvig var selv videnskabsmand. I den engelsksprogede verden er han overalt anerkendt som pionér og genial fortolker af det angelsaksiske sprog og dets litteratur, herunder det episke digt Beowulf. Selv opfattede han sig som historiker, selv om samtiden og eftertiden kun har villet anerkende ham som historieskriver. Men han var tillige en selvstændig tænker, der forholdt sig kritisk til samtidens og fortidens tænkere, dog uden at bruge deres filosofiske terminologi, hvilket den dag i dag gør det vanskeligt at forstå hans tanker.

Vi havde i den første kreds af Grundtvigforskere ikke blot en amerikansk Beowulfforsker, Kemp Malone, men også en overbibliotekar, hvis far var Grundtvigs ældste søn. Han fortalte mig imidlertid, at han først opdagede, hvem hans farfar var, da en anden ætling af Grundtvig, dommer Stener Grundtvig, henvendte sig til ham om udgivelsen af Grundtvigs brevveksling med sin første hustru, deres farmor, under sine rejser til England. Grundtvigs ældste søn havde nemlig aldrig næunt sin fars navn for sine børn!

Denne kreds af ansete personer var sikkert medvirkende til, at selskabets henvendelse til Gyldendals forlag og undervisningsministeriet om støtte til udgivelsen af Grundtig-Studier blev så godt modtaget, at Gyldendal gik ind på selv at udgive de første årgange af GrundtvigStudier, og at de i de følgende år kunne udgives med offentlig st $\varnothing t t e$. Gustav Albeck har i sine utrykte erindringer meddelt følgende om sine samtaler med Hartvig Frisch, som dengang var undervisningsminister; (Albeck havde haft ham som lærer i Aarhus Katedralskole ligesom jeg i Metropolitanskolen):

Senere mødte jeg Hartvig Frisch adskillige gange, navnlig i hans tid som undervisningsminister. Han genkendte En straks og var den samme fordomsfrie personlighed, som man huskede fra oldtidskundskabstimeme, velvilligt lyttende, præcist, men venligt spørgende, klar i tanken og rammende i sine svar. ... Navnlig husker jeg hans reaktion, da Grundtvig-Selskabets forretningsudvalg i 1949 forelagde ham tanken om statsstøtte til et 
stort anlagt projekt om i fællesskab med Det Danske Sprog- og Litteraturselskab at udgive en registrant over Grundtvigs efterladte papirer.

Litteraturselskabets daværende administrator, dr. phil. Lis Jacobsen havde afvist tanken, vistnok først og fremmest fordi hun var vokset op i et københavnsk litterært miljø, som - for at sige det pænt - var helt uden forståelse for »den Gamles « liv og virke. Mere konkret hævdede hun, at hun ville $\mathrm{d} \emptyset$, dersom hun i en længere årrække skulle samarbejde med Grundtvig-Selskabets energiske sekretær, dr. phil. Helge Toldberg, hvis iver for sagen unægtelig også fra tid til anden kunne udsætte selv varme venner af Grundtvig for alvorlige belastningsprøver.

Der var dem i selskabets styrelse, der frygtede, at Frisch af ideologiske og politiske grunde ville stille sig negativt til vor henvendelse. Nogen troens forsvarer var han ikke, ejheller modtagelig for alt for stærke verbale udslag af nationalfølelse. Men sit frisind havde han. Han bekendte sig i ord og gerning til parolen om »Frihed for alt, hvad der stammer fra Aand «. Derfor lyttede han også anspændt til Grundtvig-Selskabets daværende formand, den elskelige gamle Ribe-bisp, dr.phil C.I.Scharling, som $\mathrm{i}$ såre afdæmpede og diplomatiske vendinger gjorde rede for planen og sørgmodigt tolkede sin og selskabets skuffelse over afslaget af Det danske Sprog- og Litteraturselskab.

Men her greb Frisch ind i forhandlingerne. Hans pande med den dybe hulning rynkedes, og i meget kraftige vendinger gav han udtryk for sin misbilligelse af afslaget. Her var efter hans mening en oplagt opgave, som Litteraturselskabet, der fik årlige subsidier fra den danske stat, ikke kunne afvise. Han ville omgående sende administrator (eller styrelsen) et brev, hvori han qva undervisningsminister gav udtryk for denne holdning.

Brevet blev sendt. Jeg kender ikke dets indhold af selvsyn, men har ladet mig fortælle, at det ikke undlod at gøre et stærkt indtryk.

Ikke længe efter ramtes Frisch af den sygdom, som skulle lægge ham i graven, og kort tid efter afløstes Lis Jacobsen som administrator af Ordenshistoriografen dr. phil. Albert Fabritius. Ved nye forhandlinger tilvejebragtes et samarbejde, som førte til, at DDSL og Grundtvig-Selskabet i fællesskab kunne udgive det 30 bind store værk: »Registrant over N.F.S. Grundtvigs Pa- 
pirer « (1952-1958), et vellykket team-work af 6-8 Grundtvigforskere, deriblandt denne selvbiografis forfatter.

Vi må være Gustav Albeck taknemmelige for dette øjebliksbillede af Grundtvig-Selskabets situation ved starten af dets arbejde. Tænk, om C.I. Scharling og Henning Høirup havde ladet sig nøje med Lis Jacobsens irritation over Helge Toldbergs talestrøm og underligt forvredne skikkelse, der skyldtes polio, men som ikke havde forhindret hans fremragende evne til at forstå og datere Grundtvigs håndskrifter. Hvordan skulle vi så have overbevist nogen om værdien af Grundtvigs tanker og sammenhængen i hans billedsprog? - Hartvig Frisch forstod situationen. Han var en fremragende lærer i saglig debat. Han forstod at lade anderledes tænkende komme til deres ret. Han forstod, at Grundtvig netop var en mand, hvis tanker var forskellige fra de gængse, og at det netop derfor var Sprog- og Litteraturselskabets opgave at lade dem komme til orde og Grundtvig-Selskabets ret at fremdrage dem af glemslen.

Det er ikke Grundtvig-Selskabets opgave at støve fortidige skrifter af eller give fortidig beundring ny glans, men at vække interessen for Grundtvigs digtning og tænkning på en ny måde: at lære unge mennesker at forstå Grundtvig på hans egen måde og dermed forstå, at hans digtning og tænkning kan vedkomme os i dag, hvad enten man er enig med ham eller ej. Han var sin samtids kritiker - 'den samtid, som vor tid har fortsat. Derfor vedkommer hans tanker stadig os i dag.

Det var sådan, det lykkedes Kaj Thaning at vække interessen for Grundtvig først på Båring højskole, dernæst i sin disputats »Menneske først - Grundtvigs opgør med sig selv« (1963). Jeg er ikke enig med Thaning $\mathrm{i}$ hans fortolkning af den vending i Grundtvigs tænkning, der fandt sted i 1832 . Men jeg er enig med ham i, at Grundtvigs tænkning var et opgфr med ham selv, og at man kan følge denne tænkning ved at læse hans manuskripter. Grundtvig tænkte hele livet med en pen $\mathrm{i}$ hånden, undertiden både på vers og i prosa.

I de første tre år af Grundtvig-Selskabets eksistens var jeg bosat $\mathrm{i}$ Uppsala som dansk lektor ved universitetet dér og kunne derfor kun i feriemånederne maj-august og januar opholde mig i Danmark. Senere har jeg et år været i Grønland. Jeg kunne af den grund hverken være til stede ved den første danske Grundtvig-disputats om Henning Høirups afhandling »Tro og Erkendelse i Grundtvigs Tænkning« i 
1949 eller ved Kaj Thanings forsvar af afhandlingen »Menneske først - Grundtvigs opgør med sig selv« i 1963. Derimod fik jeg mulighed for selv at opponere (ex auditorio) ved Helge Toldbergs vigtige, men for lidt påagtede disputats »Grundtvigs symbolverden« i $1950 \mathrm{og}$ at være til stede ved Harry Aronsons teologiske Grundtvig-disputats »Mänskligt och kristet « i Lund 1960. Kaj Thaning var ikke selv til stede dér, men bad mig om et udførligt referat af handlingen, hvilket jeg også gav ham - lidet anende, at Thanings disputats skulle komme til at slutte med et voldsomt angreb ikke blot på Aronsons, men også på min Grundtvig-opfattelse. Jeg kendte ganske vist godt min uenighed med Thaning fra det grundtvigske arbejdskonvent i 1947 og hans opposition ved min egen disputats i 1954, en uenighed, der varede, så længe han levede, men ikke forhindrede os i at mødes som gode venner.

Selv om Grundtvig-Selskabet altså har spillet en væsentlig rolle for min forskning fra først til sidst, kom jeg ikke selv til at spille nogen større rolle i dets historie, før end jeg kort efter min ansættelse ved Aarhus Universitet i 1967 blev medredaktør af Grundtvig-Studier ved siden af Gustav Albeck. Min stilling som næstformand var ganske underordnet Henning Høirups sikre ledelse som formand, skønt han altid henvendte sig til mig om alle vigtige sager. Hans fratræden skete ganske pludselig under den internationale Grundtvig-konference på Den internationale Højskole i Helsing ør, som han havde været meget virksom for at få i stand sammen med Folmer Wisti (Det danske Selskab) i 100-året for Grundtvigs død, 1972.

Ved et ekstraordinært styrelsesmøde efter Høirups fratræden besluttedes det at vælge den nye formand ved hemmelig afstemning mellem styrelsens 25 medlemmer. Kaj Thaning spillede dengang en stor rolle såvel i Grundtvigforskningen som i den grundtvigske folkehøjskolebevægelse. At valget til formand ikke faldt på ham, men på mig, næstformanden, må skyldes, at de Grundtvigforskere, som styrelsen bestod af, ønskede at sætte et tydeligt skel mellem højskolebevægelsen og Grundtvigforskningen. Da der nu skulle vælges en ny næstformand, faldt valget på gudstjeneste- og salmeforskeren, professor Christian Thodberg (bl.a. kendt for sin afhandling »En glemt dimension i Grundtvigs salmer «, 1970), som jeg derved fik et langvarigt og godt samarbejde med. - Da han betroede mig, at han også var blevet næstformand i Teologisk Forening, svarede jeg: "Så kan vi jo bytte plads, når jeg er blevet træt af at være formand «. 
Hvilket jeg blev efter 7 års forløb, og Thodberg blev derefter valgt til formand, mens jeg trådte tilbage på næstformandens plads på normal vis.

Grundtvig-Selskabets stil har været kritiseret, efter min mening uden grund. Den var en naturlig fortsættelse af tonen under forskermødet i Ribe. Under Høirup var den uformel og kammeratlig. Møderne $\mathrm{i}$ forretningsudvalget foregik $\mathrm{i}$ formandens hjem og fortsatte således i min formandstid. Derefter kom de til normalt at foregå på universitetet i Århus, på formandens kontor eller andensteds, enkelte gange i Vartov, når mødet holdtes i København. Denne stil er formentlig sundere for det videnskabelige klima. Grundtvig-Selskabet er hverken en grundtvigiansk eller en selskabelig forening, men et åbent videnskabeligt selskab. Enhver Grundtviginteresseret kan melde sig ind i selskabet, men til styrelsen bliver man indvalgt af selskabets medlemmer.

Iøvrigt hænger Grundtvig-Selskabets stil sammen med sekretærens person. Den første sekretær var Helge Toldberg, som var den ivrigste af os seks til at fremme selskabets virksomhed. Efter hans tidlige død trådte den meget ældre, men lige så aktive pastor Valdemar Nielsen $\mathrm{i}$ hans sted. Han interesserede sig særlig for svenskernes forhold til Grundtvig. Da vi et år holdt årsmøde i Lund, prædikede han ved en højmesse i domkirken. Han døde samtidig med Høirups fratræden. Siden da har vores sekretær været Kierkegaardforskeren Hellmut Toftdahl i Århus, der har udgivet en afhandling om Grundtvig, set fra Søren Kierkegaards synspunkt (»Kierkegaard først og Grundtvig så«), efter min mening et meget frugtbart synspunkt, fordi de to tænkere i stor udstrækning tænker i de samme baner, selv om de ikke bruger de samme udtryk. Hovedsagen er, at både Grundtvig og Kierkegaard er modstandere af den tyske idealistiske filosofi, som fulgte efter Immanuel Kants erkendelsesteori. Forskellen er den, at Kierkegaard bruger den idealistiske filosofis kunstudtryk i sit angreb på den, mens Grundtvig sætter danske ord i stedet for disse fremmedord. Det gør imidlertid Grundtvigs tankegang vanskeligere at forstå, når man har vænnet sig til den efterkantiske filosofis fremmedord. - Til sekretær i København valgte vi senere salmeforskeren Peter Balslev-Clausen, der nu er selskabets formand.

Det er ikke min hensigt med dette korte tilbageblik i enkeltheder at omtale alle de opgaver, Grundtvig-Selskabet og dets Grundtvigfor- 
skere har arbejdet med i selskabets første 50 år. De kan ses af den række årbøger og andre skrifter, selskabet har udgivet fra 1948 til i år. Fra 1958 er formandens årsberetning trykt i hver årbog Grundtvig-Studier. De første 10 års virksomhed er sammenfattet af Henning Høirup, der indtrådte som formand efter C.I. Scharlings død. Vore årsmøder har ført os til mange minderige steder i Grundtvigs liv: til Udby, Tyregod, Præst $\varnothing$, Christianshavn og Vartov. Vi har også holdt årsmøde i Norge og Sverige, i Oslo (på Lysebu), i Kungälv og i Lund. Vi har besøgt og holdt årsmøde på højskolerne i Rødding, Askov, Båring og på Fredriksborg højskole, der nu har navnet Grundtvigs højskole. Men i de senere år har vi oftest henlagt vore årsmøder enten til Vartov eller til Aarhus Universitet, hvor mange af vore medlemmer har haft eller stadig har deres daglige arbejde som lærere eller studerende.

Men der er enkelte opgaver og begivenheder, som jeg finder grund til at fremhæve. I 1972, 100-året for Grundtvigs død, arrangerede vi som tidligere nævnt sammen med Det danske Selskab en international Grundtvig-konference på Den internationale højskole i Helsingør, og de foredrag, som dér blev holdt, enten på dansk eller på engelsk, er dels trykt, dels udførligt refereret i årbogen GrundtvigStudier for 1973.

Den vigtigste af de videnskabelige opgaver, Grundtvig-Selskabet i de forløbne år har gennemført, er uden tvivl udarbejdelsen af de 30 bind »Registrant over N.F.S. Grundtvigs Papirer«, som efter hans enkes død blev overladt som gave fra hende til Rigsarkivet, og som nu befinder sig i Det kgl. Biblioteks håndskriftsamling. De har hidtil kun været ordnet i 565 fascikler, indsat i større kapsler. Ordningen skyldes arkivsekretær J $\phi$ rgen Bloch. Denne ordning er stadig bevaret som »Grundtvig-arkivet«. Hertil kommer Grundtvig-manuskripter fra andre dele af håndskriftsamlingen. Denne umådelige papirmængde består af kun undtagelsesvis daterede manuskripter, i meget stor udstrækning udkast til trykte eller utrykte arbejder på vers og i prosa, ordnet efter indhold, som det kan ses i Lauritz Nielsens "Katalog over danske og norske Digteres Originalmanuskripter i Det kongelige Bibliotek«, 1. Hefte, København, Ejnar Munksgaard - 1941.

Opgaven bestod i at udskille de enkelte manuskripter, angive deres indhold og datere dem efter de særlige kriterier, som blev udarbejdet af Helge Toldberg og Gustav Albeck. P. gr. af manuskriptmængden måtte opgaven fordeles på Grundtvigforskere med særligt kendskab 
til de forskellige dele af Grundtvigs meget store interesseområde. Dette store arbejde kunne ikke udføres uden offentlig støtte til de enkelte medarbejdere. Det lykkedes at opnå denne støtte, ikke mindst ved et samarbejde med Det danske Sprog- og Litteraturselskab, der gennem professor Peter Skautrup førte tilsyn med hele arbejdet ved siden af Henning Høirup på Grundtvig-Selskabets vegne. Arbejdet iværksattes oprindelig ved en særbevilling fra L. Zeuthens Mindelegat allerede i februar 1949 med Høirup, Albeck, Thaning og Toldberg som de første medarbejdere. Senere kom efterhånden flere til, dr. theol. K.E. Bugge, valgmenighedspræst Uffe Hansen, cand.mag. Steen Johansen (da han var færdig med Grundtvig-bibliografien), cand.mag. Niels Kofoed og undertegnede, da jeg var færdig med min disputats og dens fortsættelse, der med et citat af Grundtvig fik titelen »Den sælsomme forvandling i N.F.S. Grundtvigs liv« (1956). Registrantens 1. bind udkom 10 år efter selskabets stiftelse, 1957, og det 30. bind 1964. I det 29. bind finder man bl.a. dr. phil. Helge Toldbergs redegørelse for de dateringskriterier, han forud for arbejdet havde fremlagt $i$ en tidsskriftartikel (i Nordisk tidskrift för bok- och biblioteksväsen), men nu suppleret med yderligere principper og oplysninger. Selv døde han samme år, 50 år gammel. Andre dateringskriterier har Kaj Thaning udarbejdet og fremlagt sammesteds. Hans livslange arbejde med Grundtvig sluttede dagen efter hans 90 års fødselsdag i 1994.

En enkelt lille ting fra de år, da jeg var Grundtvig-Selskabets formand, vil jeg nævne, fordi den drejer sig om forholdet mellem Grundtvigforskningen og Søren Kierkegaardforskningen. En dag i 1974 blev jeg ringet op af P.G. Lindhardt, der stadig var professor i kirkehistorie på Aarhus Universitet. Han havde tidligere særskilt udgivet og kommenteret Kierkegaards angreb på den officielle kristendom i tidsskriftet "Øieblikket « og havde nu i sinde (på Københavns Universitets Institut for Kirkehistories vegne) at udgive og kommentere Grundtvigs prædikener i det samme kirkeår, i hvilket »Øieblikket« udkom, 1854-55, under titelen »Konfrontation«. Professor Lindhardt spurgte mig nu, om Grundtvig-Selskabet kunne tænke sig at indbyde sine medlemmer til at subskribere på denne udgave på de samme betingelser som medlemmerne af Selskabet for Danmarks Kirkehistorie, dvs. med en rabat på 50\%. »Ja, naturligvis!« svarede jeg $\varnothing$ jeblikkelig. Og det viste sig at være et tilbud, som selskabets medlemmer modtog med stor interesse. Bogen blev sat og trykt så 
billigt som muligt og tilsendt subskribenterne af P.G. Lindhardt og mig personligt. Vi sad over for hinanden, da vi lagde bøgerne i konvolutter på Aarhus Universitet. Den situation glemmer jeg ikke!

Et år efter meddelte Christian Thodberg mig, at han havde fået Institut for Kirkehistorie til på samme måde at udgive Grundtvigs prædikener fra det følgende kirkeår under titelen »Regeneration «. Bogen »Konfrontation « indeholder udover Grundtvigs prædikener en »Indledning « på 18 sider, en »Kommentar « på 16 sider og en »Efterskrift « på 10 sider, men ingen fodnoter eller andre noter til prædikenerne. Og Lindhardt har sat sit eget navn over titelen »Konfrontation«. Der er altså ikke tale om nogen sammenblanding af Grundtvigs tekst og Lindhardts kommentar. I efterskriften (s. 208) hedder det: »Der er ikke grund til at tro, at Grundtvig personlig skulle være bragt i alvorlig anfægtelse, unægtelig havde kirkestormen gjort det dybeste indtryk på ham...«. Lindhardt mener, at det var »hensynet til den opskræmte menighed «, der fik Grundtvig til »idelig ... at forsikre, at vi må ikke lade os forskrække, forurolige, forvirre etc.« - En fodnote til dette sted lyder imidlertid: »Jfr. dog Weltzers oplysning (»Grundtvig og Søren Kierkegaard« 1952 s. 83f.), med Grundtvigs sønner som kilde, at Grundtvig under kirkestormen forbød at Kierkegaards navn nævntes i hans hus!« Denne sidste oplysning viser efter min mening, at Lindhardt har indset, at Grundtvig virkelig var alvorligt anfægtet af Kierkegaards kirkestorm. Det er der efter min mening heller ikke grund til at tvivle om. - Bogens værdi ligger netop i, at den giver anledning til alvorlig eftertanke over Grundtvigs forhold til Kierkegaard.

Grundtvig-Selskabets betydning ligger overhovedet deri, at det gennem de hidtil udgivne tekster af Grundtvig og skrifter om Grundtvig - de hidtil udgivne 47 bind »Grundtvig-Studier«, de 25 bind »Skrifter udgivne af Grundtvig-Selskabet « og de 30 bind »Registrant over N.F.S. Grundtvigs Papirer « - har gjort dette forfatterskab tilgaengeligt. Men hertil kommer de udgaver af Grundtvigs prædikener, hans »Dagbøger og Udtogsbøger« og skoleskrifter (»Grundtvigs skoleverden i tekster og udkast « I -II udg. af K.E. Bugge, 1968), som hidtil kun delvis har været tilgængelige i bogform.

Grundtvig-Selskabets hovedopgave har fra begyndelsen været en fuldstændig, videnskabeligt brugbar udgave af dette vort største forfatterskab, omfattende både hvad Grundtvig selv har ladet trykke og hvad han af forskellige grunde har ladet ligge utrykt. Det er efter 
min mening både rimeligt og nødvendigt at opdele en sådan udgave i forskellige rækker efter deres indhold. Den del af Grundtvigs forfatterskab, som hidtil er fuldstændigst udgiven, er hans digtning. Den hidtil ufuldstændigst kendte er hans prosa. Grundtvigs salmer og personlige religiøse digte er to gange udgivet i 5 bind. Den 1. udgave begyndte at udkomme, mens Grundtvig endnu levede, i 1868, det sidste bind kom i 1881. Den 2. udgave udkom ligeledes i 5 bind 19441951. Denne udgave er genoptrykt i 10 bind. Til begge udgaver findes tekstkritiske tillæg, men de er ikke videnskabeligt tilfredsstillende i dag. Der savnes også en tilfredsstillende kommentar til at gøre dem fuldt forståelige i dag. Af hele Grundtvigs øvrige digtning, hans »Poetiske Skrifter «, findes der en udgave i 9 bind, 1880-1930, påbegyndt af Grundtvigs søn, Svend Grundtvig, som døde inden dens færdiggørelse. Den er siden tilendebragt af C.J. Brandt og Georg Christensen. Den er smuk, men hverken fuldstændig eller videnskabeligt tilfredsstillende, idet Svend Grundtvig indførte sin egen retskrivning i sin fars tekster og udelod nogle af de mest personlige digte. Nogle af disse er blevet kendt gennem to nyere udgaver, der medtager forskellige udvalg af Grundtvigs prosa: N.F.S. Grundtvigs Udvalgte Skrifter ved Holger Begtrup I-X, 1904-1909 og Værker i Udvalg ved Georg Christensen og Hal Koch, 1940-1949 (De forkortes sædvanligvis US og VU.)

Grundtvig-Selskabets forskere har med Christian Thodberg i spidsen påbegyndt en fuldstændig udgave af Grundtvigs pradikener fra hans ansættelse som sognepræst i Præst $\varnothing$ i 1821 indtil ansættelsen i Vartov 1839, som nu videreføres under Thodbergs ledelse. Gustav Albeck har udgivet Grundtvigs Dag-og Udtogsbøger i 2 bind, hvoraf det første indeholder hele teksten, det andet Albecks udførlige kommentar. Denne sidstnævnte udgave kunne efter min mening tænkes som den naturlige indledning til en fuldstændig udgave af Grundtvigs prosa.

En række helt for sig udgør Grundtvigs breve. Allerede kort efter Grundtvigs død udkom der interessante brevvekslinger, der har betydning for forståelsen af hans forfatterskab, men de er langtfra fuldstændige. Det samme gælder de to bind »Breve fra og til N.F.S. Grundtvig«, der udkom 1924-28.

Ikke blot omfanget af dette uoverkommelige forfatterskab, men også den faktiske indflydelse, det fik i samtid og eftertid, gør, at man ikke kan komme uden om dets positive værdi, uanset om man slutter 
sig til Grundtvigs tanker eller ej. Dette medfører også, at Grundtvigforskningen ikke kan indskrænkes til selve Grundtvigs forfatterskab, men må udvides til også at omfatte dets eftervirkninger, dets virkningshistorie, hvilket særlig er fremhævet af professor dr. theol. Anders Pontoppidan Thyssen, som er medlem af Grundtvig-Selskabets styrelse.

Denne udvidelse i forhold til de emner, som de seks forskere ved Ribemødet var optaget af, er det særlig vigtigt at være opmærksom på, dels fordi Grundtvigs eftervirkninger ingenlunde $\mathrm{i}$ enhver henseende stemmede overens med Grundtvigs oprindelige tanker, dels fordi Grundtvig selv forandrede sine tanker i løbet af sit lange forfatterskab. Et er Grundtvig, et andet grundtvigianismen.

Det er også nødvendigt at holde Grundtvigs kirkelige tanker ude fra hans skoletanker og hans folkelige grundtanker. Men det var først i 1830erne, nødvendigheden af denne adskillelse blev ham selv fuldt bevidst.

Skal man planlægge en fuldstændig udgave af hele Grundtvigs forfatterskab - og det er naturligvis den hovedopgave, Grundtvig-Selskabet fra begyndelsen har forestillet sig - er det efter min mening nødvendigt at inddele den i flere forskellige rækker, indenfor hvilke de enkelte numre trykkes i kronologisk orden og således, at der skelnes skarpt mellem på den ene side hvad Grundtvig selv har udgivet og dermed taget ansvar for som led i den religiøse, videnskabelige eller pædagogiske og politiske eller folkelige debat, og på den anden side hvad han har ladet ligge utrykt, men hvad der alligevel afslører hans personlige tankegang. Taler og prædikener indtager en mellemstilling, fordi det strengt taget er uvist, om Grundtvig har sagt alt. hvad han har nedskrevet, men på den anden side klart, at han ofte har sagt meget mere, end han på forhånd havde nedskrevet. Som fremhævet af Thaning tænkte Grundtvig med en pen i hånden, så man kan følge hans tanker ved at læse, hvad han skrev. Men man må ikke glemme, at han langtfra altid offentliggjorde, hvad han først havde skrevet.

Der er rækker af forfatterskabet, som tilnærmelsesvis er fuldstændigt udgivet, selv om Grundtvig ikke selv har gjort det. Dette gælder først og fremmest hans salmer og personlige religiøse digte, men derimod ikke den udgave af hans »Poetiske Skrifter«, som hans søn Svend Grundtvig påbegyndte og Georg Christensen afsluttede i 1930. Den er tillige forlængst udsolgt og antikvarisk meget sjælden i fuld- 
stændig stand, da forlaget blev brandhærget i forrige århundrede. Der behøves altså en ny, fuldstændig og videnskabeligt brugbar udgave af Grundtvigs ikke-religiøse digtning.

Grundtvigs prosaiske forfatterskab er langt mindre fuldstændigt udgivet og derfor langt mindre kendt, også fordi Grundtvigs tænkning fulgte ganske andre baner end samtidens $\varnothing$ vrige tænkning. - I to henseender er der gjort væsentlige fremskridt i Grundtvig-Selskabets levetid og af Grundtvig-Selskabets forskere, dels ved Gustav Albecks udgave af Grundtvigs dagbøger og »Udtogsbøger«, dvs. uddrag af hans læsning som ung, dels ved Chr. Thodbergs udgave af Grundtvigs prædikener, der i høj grad adskiller sig fra de af Grundtvig selv udgivne prædikensamlinger. Der savnes dog stadig en udgave af Grundtvigs allerførste prædikener på Langeland, forud for krisen i 1810.

Men det, der først og fremmest savnes, er en fuldstændig udgave af hele hans $\emptyset$ vrige forfatterskab, dvs. hans opsigtvækkende deltagelse i samtidens debat og i endnu højere grad af de grundtanker, som lå bag hans menneskesyn og historiesyn. Det drejer sig om de tanker, der lå bag hans deltagelse i politik og folkeopdragelse, hvad man i dag kalder »adult education«, hvilket for Grundtvig var forudsætningen for demokrati.

Kimen til disse tanker er nedlagt i tidsskriftet Danne-Virke, som Grundtvig udgav 1816-19. Den største overraskelse, jeg har fået siden Grundtvig-Selskabets start, var det derfor, da Aarhus Universitets grafiske medarbejder J $\phi r n$ Bergmann i 1983 forærede mig et meget smukt fotografisk optyk af hele dette tidsskrift: »Udgivet i anledning af N.F.S. Grundtvigs 200-aars dag." Restoplaget af disse fire små bind erhvervedes et par år senere af Kirkeligt Samfund, der lod det sælge til nedsat pris i Vartov.

Det var ikke Grundtvig-Selskabet, der fejrede 200-året for Grundtvigs fødsel, men vi var dog med, da der i det år på engelsk, tysk og fransk blev udsendt en bog om Grundtvig, hvis formål var at give en indføring i Grundtvigs hovedtanker og grundtvigianismen indtil år 1900. Indholdet af denne bog blev samme år i ændret og udvidet skikkelse også udgivet på dansk under titelen »Grundtvig og grundtvigianismen i nyt lys « af forlaget ANIS i samarbejde med Det danske Selskab, ligeledes under redaktion af Christian Thodberg og Anders Pontoppidan Thyssen. 
Da Thodberg i marts 1995 trak sig tilbage fra formandsposten, blev salmeforskeren, lic. theol. Peter Balslev-Clausen, i stedet valgt til formand. Vi har kendt hinanden i mange år, og det var mig derfor en stor glæde, at valget faldt på ham. Det er ikke uden betydning, at formanden for Grundtvig-Selskabet er knyttet til Københavns Universitet, når Centeret for Grundtvig-studier nu er placeret ved Aarhus Universitet. Grundtvig-arkivet befinder sig jo i København. Men en fuldstændig fotokopi af arkivet er placeret ved Aarhus Universitet, tillige med et voksende Grundtvig-bibliotek. Det er Grundtvig-Selskabets nuværende formand, der har været medvirkende til, at Grundtvig-biblioteket på Vartov nu er flyttet ind i rummelige og veludstyrede lokaler, så at det lige så vel som Aarhus Universitet er egnet til studiested for Grundtvigforskningen. Det er af stor betydning, at selve originalerne til Grundtvigs manuskripter befinder sig på Det kgl. Bibliotek i København.

To vigtige situationer i Grundtvig-Selskabets liv er knyttet til Sandbjerg slot ved Sønderborg, som er Aarhus Universitets ejendom og bruges til konferencer og studieophold for forskere. Første gang var i 1964, året efter at Kaj Thaning havde forsvaret sin disputats »Menneske først - Grundtvigs opgør med sig selv«, der som nævnt slutter med et skarpt angreb på Harry Aronsons Grundtvigopfattelse i disputatsen »Mänskligt och kristet«. Aronsons svar er trykt i Grundtvig-Studier 1964. Men den store forskel mellem de to forskeres synspunkter og metoder nødvendiggjorde en nærmere mundtlig forhandling, som fandt sted ved et forskerstævne på Sandbjerg den 28.-31. august 1964, som er omtalt i biskop Høirups beretning om Grundtvig-Selskabets virksomhed i Grundtvig-Studier 1965 s. $117 \mathrm{ff}$.

I 1988 oprettedes på Aarhus Universitet et Center for Grundtvigstudier, hvortil Grundtvig-Selskabets formand Christian Thodberg sammen med professor Anders Pontoppidan Thyssen og dr. theol. Jens Holger Schjørring var initiativtagere. Dette center afholdt i september 1989 et internationalt forskermøde på Sandbjerg slot. Ved dette møde besluttedes det at etablere et samarbejde mellem Grundtvig-centeret og Grundtvig-Selskabet, der indledtes derved, at foredragene på dette møde tryktes sammen med Grundtvig-Selskabets bidrag i Grundtvig-Studier 1989-90. Det var ved denne lejliighed en stor fornøjelse for mig påny at møde Harry Aronson og at stifte bekendtskab med de engelske og tyske forskere, som det var lykkedes Jens Holger Schjørring at etablere forbindelse med. Det er dette 
samarbejde mellem Grundtvig-Selskabet og Center for Grundtvig-studier ved Aarhus Universitet, der $\mathrm{g} \emptyset \mathrm{r}$ det muligt at forestille sig videreførelsen af den Grundtvig-forskning, der for halvtreds år siden blev grundlagt af Grundtvig-Selskabet.

Til at begynde med kunne man i Grundtvig-Selskabet være bange for, at trykningen af enkelte særlig interessante manuskripter fra Grundtvig-arkivet ville forhindre en fuldstændig udgivelse af Grundtvigs efterladte prosamanuskripter. Alene mængden af disse manuskripter har jo hidtil afskrækket både forlæggere og udgivere fra en sådan udgave. Men erfaringen viser, at de manuskripter, der er offentliggjort - især i Grundtvig-Studier og i prædikensamlinger snarere har gjort opmærksom på, hvilke ejendommelige tanker, der her ligger gemt. Et enkelt eksempel på dette forhold er de tekster, der er trykt i Grundtvig-Studier $1995 » O m$ Troens Indflydelse paa Jordlivet eller Om Kirke og Stat « ved Grundtvig-centerets leder, ph.d. Kim Arne Pedersen. Så på et eller andet tidspunkt må trangen til at kende Grundtvigs særegne tænkemåde og udtryksmåde føre til, at man tager springet og vover den fuldstændige udgivelse af Grundtvigs samlede Skrifter. Den lader sig ikke gennemføre af en enkelt forsker og udgiver, men må efter min mening - ligesom registreringen af Grundtvigs efterladte papirer - gennemføres som et større eller mindre team-work og med offentlig støtte.

Men dette må tilkomme fremtidens Grundtvigforskning. Det er mit håb, at Grundtvig-Selskabet i samarbejde med Center for Grundtvigstudier ikke blot må udkaste planen til dette arbejde, men også få del i selve arbejdet. 